Ethiopian Journal of Environmental Studies \& Management 10(2): 229 - 240, 2017.

ISSN:1998-0507

doi: http://dx.doi.org/10.4314/ejesm.v10i2.9

Submitted: December 06, 2016

Accepted: March 13, 2017

\title{
MORPHOMETRIC AND LANDUSE ANALYSIS: IMPLICATIONS ON FLOOD HAZARDS IN ILESA AND OSOGBO METROPOLIS, OSUN STATE NIGERIA
}

\author{
AKINWUMIJU, A.S. \\ Department of Remote Sensing and GIS, Federal University of Technology, Akure, \\ Nigeria \\ Email: ojhakin@yahoo.com
}

\begin{abstract}
This study assessed the morphometric, landuse and lithological attributes of five basins (Iwaraja, Ilesa, Olupona, Osogbo I and Osogbo II) with particular reference to flood hazards in Ilesa and Osogbo metropolis, Osun State Nigeria. Ilesa town is situated within Iwaraja and Ilesa basins while Osogbo metropolis spread across Olupona, Osogbo I and Osogbo II basins. Twenty-three morphometric parameters were computed from DEMbased vector data for the sub-basins using GIS techniques. Image analysis technique of unsupervised classification was adopted to generate landuse map for the sub-basins. Classification was based on six landuse classes that were identified on the satellite imagery and confirmed by field investigations. Statistical analyses of the classification results were undertaken. Also, lithology of the basin was analyzed. Morphometric characteristics of Osogbo I, Osogbo II and Olupona drainage basins have the tendency to trigger high impact floods while flood hazard is relatively low in Iwaraja and llesa basins. However, relief attributes suggest possible exposure to flash flood particularly along the banks of main channel of llesa basin. Landuse analysis indicates that more than 85 percent of Osogbo I, Osogbo II and Olupona basins are built up and consequently impervious, leading to low infiltration-runoff ratio. Less than 32 percent of Iwaraja and llesa basins are built up while more than 66 percent of the basins are covered by vegetation of varying degrees of thicknesses, leading to high infiltration-runoff ratio. Occurrences of heavily fissured quartz schist in Iwaraja basin also contribute to high infiltration potential in part of Ilesa town. Consequently, Osogbo metropolis is highly susceptible to flood hazards compared to llesa town where potential flood dangers are easy to manage.
\end{abstract}

Keywords: Morphometry, Landuse, Flood Hazards, Exposure, Urbanization

\section{Introduction}

For several decades flood has been a global annual occurrence that usually claims both lives and properties, leading to sudden reverse in development and drastic fall of standard of living of humans (Komolafe et al., 2015). The occurrence of flood has been linked to many causes that could be natural or manmade. The natural causes include 
heavy rainstorm, prolong torrential rainfall, ocean storms and tidal waves (Atedhor et al., 2011; Adedeji et al., 2012; Agbonkhese et al., 2014; Ijigah and Akinyemi, 2015). Anthropogenic causes include sudden burst of major trunk water pipes, dam and dyke failure and excessive ecological release from overflowing dam (Atedhor et al., 2011; Olawuni et al., 2015). In some cases, the occurrence of flood downstream of a major river might not be connected to in situ rainfall; but the accumulation of excessive discharges from tributaries at the upper course of such a given river. In this case, causes of flood are usually extensive.

Flood would remain an event if it does not inflict damages on lives and properties of humans as well as economic activities and natural resources. But when humans and their economic activities, properties and natural resources are exposed to flood, the end result is disaster, which (many at times) is capable of destroying the livelihood of people. Thus, while humans (in some cases) will have to adapt and cope with the menace of flood disaster, its occurrence could (sometimes) be averted. This could be achieved through landuse planning and urban renewal, reduced interference with the hydrological system and sound sustainable management of natural resources and the environment.

In Nigeria, flood usually occurs in form of coastal flood, river flood, flash flood, urban flood, dam failure-induced flood and ecological release flood (Komolafe et al., 2015). Among these, flash flood and urban flood are the commonest and the most frequent, which have become seasonal occurrences in many Nigeria's settlements. The first incidence of urban flood came up 1948 in
Ibadan when Ogunpa River flooded its plain within the metropolis, causing severe damages to lives and properties (Adedeji et al., 2012). Ever since, flood has been a major disaster laden occurrence across Nigeria. Poignantly, flood occurrence has been on the increase and of greater impacts in Nigeria's settlements since year 2000. This is not unconnected with climate change and variability, leading to shorter raining season, increased raining days and higher intensity and duration of rainfall. The effect of climate change has equally been aggravated by reduced vegetation cover and vitality, buildup of natural flood plains, channel modification and obstruction of river courses. Recent population explosion and its consequent urbanization have resulted to increased exposure of lives and properties to flood hazards in Nigeria. Poignantly, exposure has been on the increase due to lack of proper urban planning and policy, leading to indiscriminate and uncontrolled development in virtually all Nigerian settlements. As it is in the developed countries, there is the need to shift from flood disaster management to flood prevention and mitigation. In this case, studies on flood events should cut across an entire drainage basin as against the conventional in situ flood studies that are peculiar to developing countries such as Nigeria.

In Nigeria, studies on flood have been limited to flood hazard modeling/mapping, exposure and vulnerability analysis (Komolafe et al., 2015). Also, study site is usually limited to settlement boundary and flood disaster impacted area. Moreover, studies on flood would better be based on an entire drainage basin. This is because; the tendency of flood event occurring in a 
given location is a function of the characteristics of the host basin and the nature of its hydrological partitioning. Thus, basin characteristics such as morphometry and landuse have been observed to have decisive influence on basin's hydrological partitioning vis-à-vis flood hazard (Ayandike and Phil-Eze, 1989; Pitlick, 1994; Ifabiyi, 2004; Jimoh and Iroye, 2009). For instance, morphometric parameters such as Elongation Ratio, Form Factor and Circularity Ratio could give meaningful explanation to potential response of a given basin to sudden rainstorm. In this case, an elongated basin would be characterized by short concentration time (leading to faster rise in channels' water level) but low and extensive peak discharge. Also, parameters such as Length of Overland Flow, Drainage Density, Drainage Texture and Infiltration Number would give an insight to runoff characteristics of a given basin. Thus, high Drainage Density, low Length of Overland Flow and high Infiltration Number are all indicators of potential high runoff, which invariably could result to flooding.

Studies have revealed that vegetation usually play a significant role in hydrological partitioning (Ifabiyi, 2004; Jimoh and Iroye, 2009). For instance, thick vegetation (such as forest) usually intercepts rainwater and thus, retards the rate of surface accumulation of rainwater. Likewise, plants play a significant role in evapotranspiration, which usually account for larger percentage of water vapor in the earth atmosphere. Also, a sizeable volume of water are usually been locked up in plant tissues. Vegetation also retards the formation of surface runoff on forest floor, thus reducing flood hazard and soil erosion. On the other hand, impervious surfaces such as built up area and compacted bare ground are usually characterized infiltration potential and high runoff, leading to high tendency towards flood occurrence.

Overtime, basin characteristics usually change in response to formprocess interaction. In turn, these changes also determine the nature of and variability of hydrological partitioning to a great extent. Thus, there is the need to investigate basin characteristics periodically at different levels of order (Ajibade et al., 2009). This would provide a lead to how hydrological challenges could be adequately tackled within a basin. This study therefore, attempts to investigate the environmental characteristics of some selected drainage basins with a view to understanding the impact of basin conditions on the exposure of human settlements to flood hazards.

\section{Study Area}

In this study, five (5) sub-basins were investigated in Osun Watershed, central Southwestern Nigeria (Figure 1). The basins are located within $7^{\circ} 49^{\prime} \mathrm{N}, 4^{\circ} 30^{\prime}$ $\mathrm{E}$ and $7^{\circ} 34^{\prime} \mathrm{N}, 5^{\circ} 00^{\prime} \mathrm{E}$, in the tropical rainforest region of Southwestern Nigeria. The studied sub-basins host the two largest and most populous settlements (Ilesa and Osogbo Metropolis) in Osun Drainage Basin. Ilesa and Osogbo Metropolis (in Osun State) have been confronted with numerous flood disasters since year 2000 and flooding has become an annual event particularly in the latter. Ilesa town is situated within two (Ilesa and Iwaraja) drainage basins. Flash flooding is common within Ilesa basin particularly along the banks of its main channel and flood plain. But in the recent time, flood events have been kept under control in 
Ilesa town. Osogbo metropolis (Capital of Osun State) extends mainly across three (Olupona, Osogbo I and Osogbo II) drainage basins in the low-lying area of Osun Watershed. Annually, high density area of Osogbo metropolis is usually inundated by flood water in response to thunderstorms and torrential rainfall at the peak of raining season. The choice of these settlements is connected to the similarity in their climatic conditions and the role they play as the major commercial, industrial and cultural centers of Osun State, Southwestern Nigeria. A notable and most devastating flood disaster struck both settlements in 2012 , leading to loss of many lives and properties (Komolafe et al., 2015).

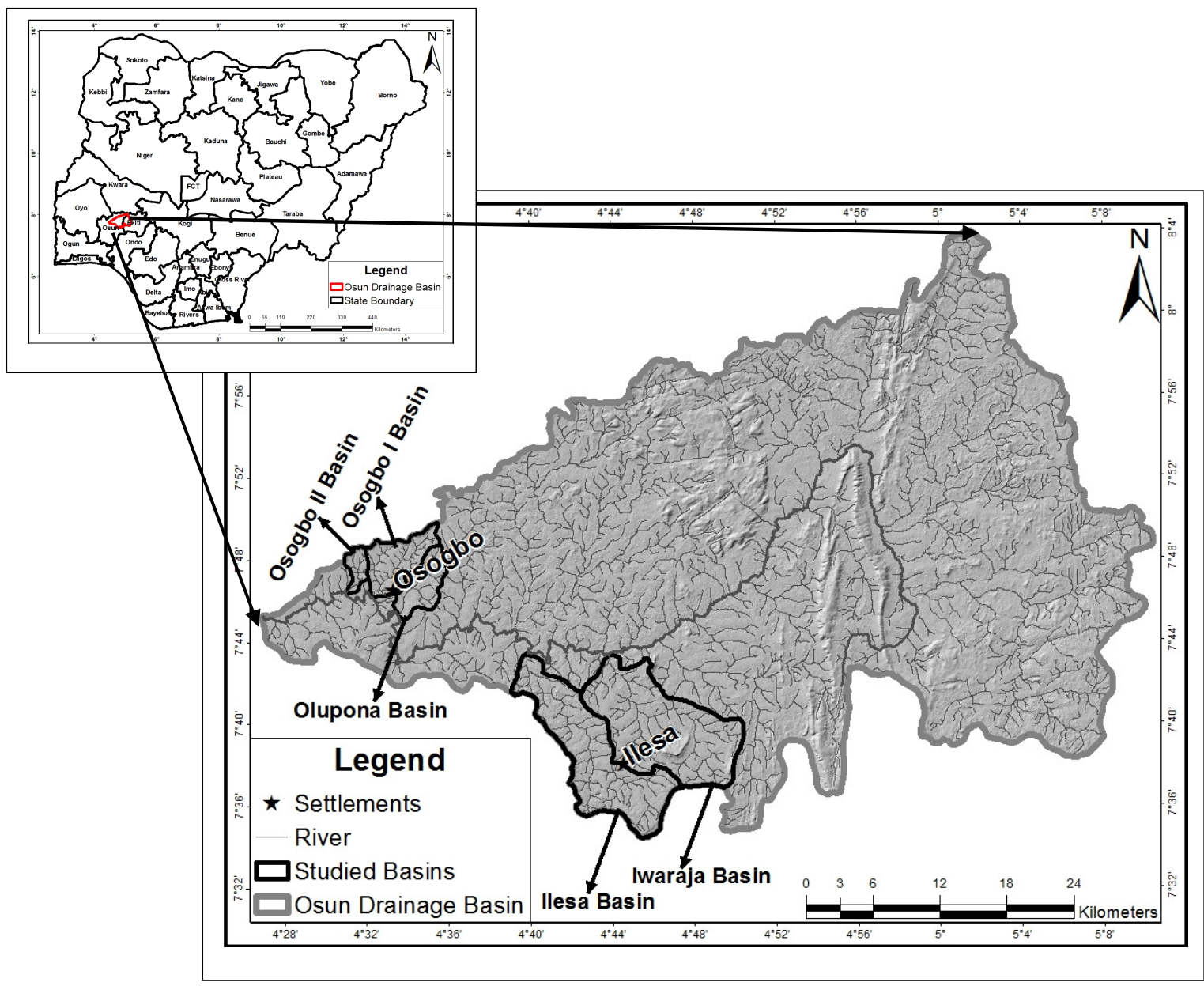

Figure 1: Map of the Study Area showing a): Nigeria's State Boundaries; b): Studied Sub-

The climate of the studied drainage basins is characterized by a long rainy season from March/April through to October. The study area lies within the Humid Tropical Climatic Zone that normally experience double maximal rainfall that peaks in July and October. Precipitation is uniformly high across the basin (between 1,650 and 1,700 $\mathrm{mm}$ per annum) and the only dry months are January and February. Relative humidity rarely dips below $60 \%$ and fluctuates between $75 \%$ and $90 \%$ for most of the year (Orimoogunje et al., 2009). During the peak period of the rainy season, cloud cover is nearly continuous resulting in 
mean annual sunshine hours of 1,600 and an average annual temperature of approximately $28^{\circ} \mathrm{C}$.Air quality in the study area is generally good, although minor industrial activities and different forms of road traffic have increased in recent years particularly within the urban centers leading to the formation of urban heat island in Osogbo metropolis (Babatola, 2013).

Deciduous rainforest of the study area can further be sub-divided into three types. These include the disturbed rainforest, the light forest and the patches of thick forest. The disturbed rainforest is the anthropogenic impacted rainforest with many randomly distributed open spaces as a result of human activities such as agriculture, mining, lumbering and fuel wood harvesting. The light forest is emerging forest at the stage of secondary succession that is common on the slightly weathered rocks. The patches of thick forest are the few natural rainforests of the Southwestern Nigeria that are relatively protected from encroachment. These include the forest reserves and traditionally preserved forests that are consecrated to some traditional religions and festivals in Yoruba Land.

\section{Methodology}

Details of the data used in this study are presented in Table 1. Initial stage of the research involves the extraction of river network for the sub-basins based on their boundaries as dictated by drainage divides. Strahler (1964) approach was adopted to order the rivers of the basins. Twenty-three morphometric parameters were computed from DEM-based vector data for the sub-basins. The parameters and corresponding formulae are presented in Table 2. Image analysis technique of unsupervised (maximum likelihood) classification was adopted to generate landuse map for the sub-basins. Classification was based on six (6) landuse classes that were identified on the satellite imagery and confirmed by field investigations. Quantitative statistical analyses of the classification results were undertaken. To complement the morphometric and landuse analysis, lithology of the basin was analyzed. All analyses were undertaken in ArcGIS 10.4.1 environment. In order to achieve the aim of this study, all the basin characteristics were comparatively evaluated.

\section{Results}

The computed basin parameters are presented in Table 3. Sixty percent of the basins are drained by $4^{\text {th }}$ order river network while the remaining 40 percent are drained by $3^{\text {rd }}$ order river network. Basin Area ranges from $97.28 \mathrm{~km}^{2}$ to $5.90 \mathrm{~km}^{2}$ with the highest and lowest values recorded for Iwaraja and Osogho II respectively. The highest and the lowest Basin Perimeters are recorded for Ilesa basin and Osogbo II respectively. Mean Bifurcation Ratio varies from 2.84to 4.32 with the lowest value occurring in Ilesa and Osogbo I and the highest value occurring in Ilesa basin. Bifurcation Ratio is highly variable in Ilesa and Osogbo I compared to other basins. Stream Number ranges from 12to 90with length varying from $9.1 \mathrm{~km}$ to $124.66 \mathrm{~km}$. While the highest Stream Number and length are recorded for Iwaraja basin, the highest Mean Stream Length is recorded for Ilesa basin. Stream Frequency is high in Osogbo I and Osogbo II ( $\mathrm{S}_{\mathrm{f}}=2.1$ and 2.0 respectively) and it is low in Olupona $\left(\mathrm{S}_{\mathrm{f}}=0.9\right)$, Iwaraja $\left(S_{f}=0.9\right.$ and Ilesa $\left(S_{f}=0.8\right)$. the 
highest Main Stream Length is recorded for Ilesa $(15.59 \mathrm{~km})$ and lowest is computed for Osogbo I (1.59 km). Length of Overland Flow ranged from 0.31to 0.40 with the highest and the lowest value occurring in Olupona and Osogbo I respectively. The highest Basin Length is recorded for Ilesa basin (19.88 $\mathrm{km})$ and the lowest is recorded for Osogbo II $(4.32 \mathrm{~km})$. Drainage Density ranges from 1.2 in Olupona and Iwaraja basins to 1.6 in Osogbo I. The highest Drainage Texture is recorded for Osogbo I (2.12) while the lowest occurs in Olopona basin (0.89). The highest and lowest Channel Gradient is recorded for Osogbo II $(10.02 \mathrm{~m} / \mathrm{km})$ and Ilesa $(3.61$ $\mathrm{m} / \mathrm{km}$ ) respectively. Maximum Basin Relief is highest in Iwaraja $(282 \mathrm{~m})$ and lowest in Osogbo II $(67 \mathrm{~m})$. Infiltration Number ranges from 3.53 in Osogbo I to 1.16 in Iwaraja. Relief Ratio varies from 0.95 in Iwaraja to 0.18 in Osogbo I. Basin Slope is high in Iwaraja (0.0177), Osogbo II (0.0155) and Olupona (0.0113) while Osogbo I and Ilesa have low Basin Slope $(\mathrm{Bs}=0.0097$ and 0.0091 respectively). Form Factor varies from 0.38 in Iwaraja to 0.21 in Ilesa while the highest and lowest Elongation Ratio is recorded for Iwaraja (0.20) and Ilesa (0.15) respectively. Circularity Ratio (Rc) ranges from 0.56 in Iwaraja to 0.35 in Ilesa with 80 percent of the studied basins having Rc values in excess of 0.5. The highest and the lowest Compactness Coefficient are computed for Ilesa (1.69) and Olupona (1.31) respectively. Texture Ratio ranges from 1.65 in Osogbo I to 0.63 in Olupona.

The percentage Built-Up Area ranges from 89.40 in Osogbo II to 24.54 in Iwaraja. Intensive Rainfed Agriculture varies from 21.93 percent in Iwaraja to 10.20 percent in Osogbo II and Shifting
Cultivation ranges from 21.80 percent in the former to 0.06 percent in the latter. While 30.39 and 29.21 percent forest cover occur within Iwaraja and Ilesa basins respectively, Olupona, Osogbo I and Osogbo II are void of forest cover. The highest and lowest percentage of rock outcrop occurs in Olupona (2.06) and Osogbo II (0.34) respectively.

The lithology of Iwaraja basin is characterized by Banded Gneiss (46.57\%), Quartz Schist (26.46\%), Amphibole Schist $(20.76 \%)$ and Granite Gneiss (6.21\%). Ilesa basin is predominantly underlain by Amphibole Schist $(76 \%)$ with minor occurrence of Banded Gneiss (17.07\%) and Quartz Schist $(6.93 \%)$. The lithology of Olupona basin is dominated by Mica Schist $(93.54 \%)$ with slight occurrence of Banded Gneiss (6.46\%). While Mica Schist and Banded Gneiss occur almost at equal proportion $(56.36 \%$ and $43.64 \%$ respectively) in Osogbo I basin, the latter dominates the lithology of Osogbo II basin (underlying $98.64 \%$ of the basin) with slight representation of the former (1.36\%). In crystalline form, metamorphic rocks are characterized by low porosity and absorption capacity. However, their porosity could be enhanced by tectonic activities such as fracturing, faulting and shearing. Basin orientation is NE-SW in Olupona $\left(239^{\circ}\right)$, Osogbo I $\left(228^{\circ}\right)$ and Osogbo II $\left(249^{\circ}\right)$ while Iwaraja $\left(134^{\circ}\right)$ and Ilesa $\left(124^{\circ}\right)$ have SE-NW orientation.

\section{Discussion}

Although all the basins are elongated, Ilesa basin is more elongated. As indicated by the computed values of Elongation Ratio, Form Factor, Circularity Ratio and Compactness Coefficient, water level in the main 
channel of Ilesa basin will quickly respond to sudden heavy storm compared to other basins (Miller, 1953; Gregory and Walling, 1973; Ifabiyi, 2004; Ajibade et al., 2010; Akinwumiju and Olorunfemi, 2016). However, peak discharge will be low by being extended over a much longer period of time in Ilesa basin (Jimoh and Iroye, 2009). Thus, floods are much easier to manage within Ilesa basin compared to other basins (Strahler and Chow, 1964; Hajam et al., 2013). The computed values of Bifurcation Ratio show that Osogbo II, Osogbo I and Olupona basins are prone to flood hazards (Schumn, 1956; Rakesh et al., 2000). Likewise, results also indicate potential flood danger at the upper part of Ilesa basin owing to low Bifurcation Ratio of the $2^{\text {nd }}$ order rivers. Stream Frequency, Length of Overland Flow, Drainage Density, Drainage Texture and Mean Stream Length indicate that Osogbo I and Osogbo II are more prone to flash flood compared to other basins (Schmid, 1997; Akinwumiju and Olorunfemi, 2016). The extremely low Main Stream Length recorded for Osogbo I suggest that the basin is highly exposed to flood hazard at its lower course due to potential higher peak discharge and sudden rise in channel water level. Relief Ratio and Basin Slope indicate that sudden heavy storm will result to swift rise in water level and prolong flood water retention in the main channel of Osogbo I basin (Schumn, 1956; Hajam et al., 2013). Infiltration Number suggests high runoff for Osogbo I and Osogbo II due to relatively low infiltration potential, which cannot be unconnected with high percentage of impervious surface (Jimoh and Iroye, 2009; Hajam et al., 2013). Landuse analysis reveals that Osogbo II, Osogbo I and Olupona basins are dominated by impervious surface with patches of farmlands and outright absence of forest cover. Results show that substantial percentages of Iwaraja and Ilesa basins are covered by forest while large parts of the basins constitute agricultural landuses. Rocky outcrop is poorly represented across all the basins, indicating advanced weathering stage and occurrence of relatively thick soil profile (Akinwumiju, 2015). The lithology of the Iwaraja and Ilesa basins is dominated by meta-sedimentary and meta-igneous rocks with substantial occurrence of old granitic rocks while Olupona, Osogbo I and Osogbo II are predominantly underlain by old granitic rocks that have been subjected to intense metamorphism (Akinwumiju et al., 2016). Thus, overburden thickness and infiltration potential vary with lithologic types across the basins (Akinwumiju, 2015).

\section{Implications on Flood Hazards in Ilesa and Osogbo Metropolis}

Morphometric and landuse characteristics of Iwaraja and Ilesa basins imply that exposure to flood hazards is relatively low in Ilesa town. However, linear and relief characteristics of Ilesa basin suggest possible occurrence of flash flood along its main channel. Another reason for the relatively low flood risk in Ilesa town is the occurrence of the heavily fissured quartz schist that forms a ridge-like cuesta within Iwaraja basin. The geologic unit has high absorbing capacity, thereby forming a natural basin water discharge regulator and a prolific watershed that gives rise to many perennial rivers within the basin (Akinwumiju, 2015). The positioning of Ilesa at the upstream of its host basins could pose potential flood danger as urbanization extends downstream. This is 
because, the urbanized (impervious) upstream would lead to elevated peak discharges from lower order sub-basins due to reduced infiltration capacity (Jimoh and Iroye, 2009).

Based on the results of this study, it is adjudged that Osogbo Metropolis is highly exposed to flood hazards as a result of unfavorable morphometric characteristics and extremely high rate of urbanization of its host basins. This situation is further compounded by the absence of forest cover as well as high rainfall intensity and duration. The exposure of live and properties to flood hazards has been aggravated by the current overdevelopment of flood plains, wetland reclamation and channel modification (Orimoogunje et al., 2009). Also, uncontrolled urbanization has rendered the entire host basins (Osogbo I, Osogbo II and Olupona) almost completely impervious, meaning that larger percentage of rainwater will eventually leave the basin as runoffs. Due to shape and areal characteristics of the host basins, channel water level tend to respond quickly to sudden rainstorm in Osogbo Metropolis and the eventual flood water would maintain its level for a considerable period of time as a result of its relief characteristics that favor faster concentration of rainwater to the main channel but with reduced discharge rate.

\section{Conclusion}

Morphometric characteristics and landuse of some basins were analyzed in order to understand flood hazards within Ilesa and Osogbo metropolis in Osun State, Nigeria. Thirty basin parameters were analyzed for the five drainage basins. Results indicate that Osogbo I, Osogbo II and Olupona basins are prone to flood hazards while exposure to flood hazards is relatively low in Iwaraja and Ilesa basins. However, results suggest high risk of flash flooding along the main channel of Ilesa basin. The observed low flood risk in Iwaraja basin is attributed to the heavily fissured bedrocks that dominate the lithology of the basin. Consequently, it was observed that Osogbo Metropolis is highly exposed to flood hazards compared to Ilesa town where potential flood dangers are easy to manage. Landuse analysis indicate that more than 85 percent of Osogbo I, Osogbo II and Olupona basins are built up and thus, impervious; leading to elevated peak discharge. On the other hand, less than 32 percent of Iwaraja and Ilesa basins are built up while more than 66 percent of these basins are covered by vegetation of varying degrees of thickness, hence high infiltration. However, relief characteristics suggest possible occurrence of flash flood in Ilesa town particularly along the banks of the main channel of Ilesa basin. Therefore, while the annual flood incidence in Osogbo metropolis is connected to overdevelopment of its host basins, the occurrence of occasional flash flood in Ilesa town can be attributed to the morphometric characteristics of its host basins. Thus, the need for all-inclusive sustainable development is eminent, not only within the examined basins, but across all Nigeria's settlements.

\section{Acknowledgement}

The author is grateful to the anonymous reviewers for their suggestions. The author acknowledges the Office of the Surveyor-General of the Federation, Nigeria for providing the DEM. Appreciation also goes to National Aeronautics and Space Administration, USA for making satellite imageries 
available online for users. Many thanks also go to ESRI, USA for giving free ArcGIS multiple user licenses to my University.

\section{References}

Adedeji, O.H., Odufuwa, B.O. and Adebayo, O.H. (2012). Building Capabilities for Flood Disaster and Hazard preparedness and Risk Reduction in Nigeria: Need for Spatial Planning and Land Management. Journal of Sustainable development in Africa, 14(1): 45-58.

Agbonkhese, O., Agbonkhese, E G., Aka, E.O., Joe-Abaya, J., Ocholi, M. and Adekunle, A. (2014). Flood Menace in Nigeria: Impacts, Remedial and Management Strategies. Civil and Environmental Research, 6(4): 3240.

Ajibade, L.T., Ifabiyi, I.P., Iroye, K.A. and Ogunteru, S. (2010). Morphometric Analysis of Ogunpa and Ogbere Drainage Basins, Ibadan, Nigeria. Ethiopian Journal of Environmental Studies and Management, 3(1): 13-19.

Akinwumiju, A.S. (2015). GIS-Based Integrated Approach to Groundwater Potential Assessment of Osun Drainage Basin, Southwestern Nigeria. An Unpublished Ph.D. Thesis Submitted to the Institute of Ecology and Environmental Studies, Obafemi Awolowo University, Ile-Ife, Nigeria. 316pp

Akinwumiju, A.S. and Olorunfemi, M.O. (2016). Morphometric Analyses of Osun Drainage Basin, Southwestern Nigeria. Journal of Geography and Geology, 8(4): 9-22.
Akinwumiju, A.S., Olorunfemi, M.O. and Afolabi, O. (2016). Automated Lineament Mapping from Remotely Sensed Data: Case Study Osun Drainage Basin, Southwestern Nigeria. Ife Journal of Science, 18(1): 177-201.

Atedhor, G.O., Odjugo, P.A.O. and Uriri, A.E. (2011). Changing Rainfall and Anthropogenic-Induced Flood: Impacts and Adaptation Strategies in Benin City, Nigeria. Journal of Geography and Regional Planning, 4(1): 45-52.

Ayandike, R.N.G. and Phil-Eze, R.C. (1989). Runoff Response to Basin Parameters in Southwestern Nigeria. Annals of Geography, 71A $(1 \& 2): 75-84$

Babatola, E.B. (2013). Socio-Economic Consequences of Flood in Ilesa, Osun State, Nigeria. Geo-Studies Forum, 6: 84-93.

Gregory, K.J. and Walling, D.E. (1973). Drainage Basin Form and Process: A Geomorphological Approach, Edward Arnold, London, 456pp.

Hajam, R.A., Hamid, A, and Bhat, S. (2013). Application of Morphometric Analysis for GeoHydrological Studies Using GeoSpatial Technology -A Case Study of Vishav Drainage Basin. Hydrol Current Res. 4: 157. doi:10.4172/2157-7587.1000157

Ifabiyi, I.P. (2004). A Reduced Rank Model of Drainage Basin Response to Runoff in Upper Kaduna Catchment of Northern Nigeria. Geo-studies Forum, 2(1): 109-117

Ijigah, E.A. and Akinyemi, T.A. (2015). Flood Disaster: An Empirical Survey of Causative Factors and Preventive Measures in Kaduna, Nigeria. International Journal of 
Environment and Pollution

Research, 3(3): 53-66.

Jimoh, H.I. and Iroye, K.A. (2009). Managing High Runoff Discharge in the Urbanized Basins of Asa River Catchment Area of Ilorin, Nigeria. Environmental Research Journal, 3(2): 25-34.

Komolafe, A.A., Adegboyega, S.A. and Akinluyi, F.O. (2015). A Review of Flood Risk Analysis in Nigeria. American Journal of Environmental Sciences, 11(3): 157-166.

Miller, V.C. (1953). A Quantitative Geomorphic Study of Drainage Basin Characteristics in the Clinch Mountain Area, Virginia and Tennessee. Department of Geology, Columbia University.

Olawuni, O.P., Popoola, A.S., Bolukale, A.T., Eluyele, K.P. and Adegoke, J.O. (2015). An Assessment of the Factors Responsible for Flooding in Ibadan Metropolis, Nigeria. Journal of Environment and Earth Sciences, 5(21): 1-7.

Orimoogunje, O.O.I., Oyinloye, R.O. and Momodou, S. (2009). Geospatial Mapping of Wetlands Potential in Ilesa, Southwestern Nigeria. FIG Working Week, Surveyors Key Role in Accelerated Development, Eilat, Israel.
Pitlick, J. (1994). Relations between Peak Flows, Precipitation and Physiography for Five Mountainous Regions in Western U.S.A. Journal of Hydrology, 158: 219 - 240.

Rakesh, K., Lohani A.K., Sanjay C.C. and Nema R.K. (2000). GIS based morphometric analysis of Ajay river basin up to Sararath Gauging Site of South Bihar. J. Appl. Hydrol., 14: 45-54.

Schmid, B.H. (1997). Critical Rainfall Duration for Overland Flow an Infiltrating Plane Surface. Journal of Hydrology, 193: 45-60.

Schumn, S.A. (1956). Evolution of drainage systems and slopes in badlands at Perth Amboy, New Jersey. Geological Society of American Bulletin, 67: 597-646.

Strahler, A.N. and Chow V.T. (1964). Quantitative geomorphology of drainage basins and channel network, In. Handbook of Applied Hydrology, McGraw Hill Book Company, New York, USA

Strahler, A.N. (1964). Quantitative Geomorphology of Drainage Basins and Channel Networks. In: V.T. Chow (Ed.). Handbook of Applied Hydrology. McGraw-Hill, New York, pp. 439-476.

Table 1: Base Data and their Sources

\begin{tabular}{llllll}
\hline S/No & Data & Source & Format & Scale & Date \\
\hline 1 & SPOT DEM & & Digital & $20 \mathrm{~m}$ Resolution & 2012 \\
2 & SPOT5 Imagery & $\begin{array}{l}\text { Office of the Surveyor-General of the } \\
\text { Federation, Abuja, Nigeria }\end{array}$ & Digital & 5 m Resolution & 2008 \\
3 & Topographical Maps & Dlobal Land Cover Facility Website & Digital & $30 \mathrm{~m}$ Resolution & 2015 \\
4 & Landsat8 Imagery & Gital & $1: 50,000$ & 1960 \\
\hline
\end{tabular}


Table 2: Morphometric Parameters and Formula

\begin{tabular}{|c|c|c|c|}
\hline S/No & Parameters & Formula & Reference \\
\hline & & Linear Morphometric parameters & \\
\hline 1 & Stream Order $(\mathrm{S} \mu)$ & Hierarchical rank & Strahler (1964) \\
\hline 2 & Bifurcation Ratio $\left(\mathrm{R}_{\mathrm{b}}\right)$ & 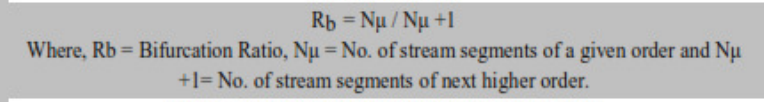 & Schumn (1956) \\
\hline 3 & Mean Bifurcation Ratio (Rbm) & $\mathrm{Rbm}=$ Average of Bifurcation Ratios of all orders & Strahler (1964) \\
\hline 4 & Stream Number (Sn) & $\mathrm{Sn}=$ Total Number of Stream Segments & \\
\hline 5 & Stream Length $(\mathrm{L} \mu)$ & Length of the stream $(\mathrm{km})$ & Horton (1945) \\
\hline 6 & Mean Stream Length (Lsm) & $\begin{array}{l}\qquad L_{\mathrm{sm}}=\mathrm{L} \mu \mathrm{N} \mu \\
\text { Where, } L \mu=\text { Total stream length of order ' } \mu \text { ' } N \mu=\text { Total no. of stream segments of order }\end{array}$ & Strahler (1964) \\
\hline 7 & Main Stream Length & Length of the Main Channel $(\mathrm{km})$ & Strahler (1964) \\
\hline 8 & Length of Overland Flow $(\mathrm{Lg})$ & $\begin{array}{l}\mathrm{L}_{\mathrm{g}}=1 / 2 \mathrm{D} \mathrm{Km} \\
\text { Where, } \mathrm{D}=\text {-Drainage Density }\left(\mathrm{Km} / \mathrm{Km}^{2}\right)\end{array}$ & Horton (1945) \\
\hline 9 & Basin Perimeter $(\mathrm{P})$ & $\mathrm{P}=$ Outer boundary of drainage basin measured in kilometers. & Schumm (1956) \\
\hline 10 & Basin Length (Lb) & $\begin{array}{l}\mathrm{L}_{\mathrm{b}}=1.312^{*} \mathrm{~A} \\
\text { Area/Shape Morphometric parameters }\end{array}$ & Gregory and Walling (1973) \\
\hline 11 & Basin Area (A) & $\begin{array}{l}\text { Area from which water drains to a common stream and boundary determined by opposite } \\
\text { ridges }\end{array}$ & Strahler (1969) \\
\hline 12 & Drainage Density $\left(D_{d}\right)$ & $\begin{array}{c}L^{D_{d}}=L \mu / A \\
\text { Where, Dd = Drainage Density }\left(K m / K m^{2}\right), L \mu=\text { Total stream length of all orders and A } \\
=\text { Area of the basin }\left(\mathrm{Km}^{2}\right) .\end{array}$ & Horton (1932) \\
\hline 13 & Stream Frequency $\left(\mathrm{F}_{\mathrm{s}}\right)$ & 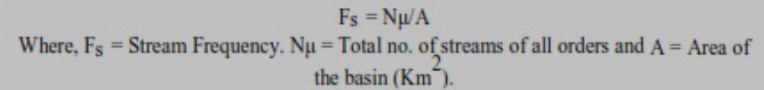 & Horton (1932) \\
\hline 14 & Drainage Texture (Dt) & $\begin{array}{c}\qquad D_{t}=N \mu / P \\
\text { Where, } N \mu=N o \text { of streams in a given order and } P=\text { Perimeter }\end{array}$ & Smith (1939) \& Horton (1945) \\
\hline 15 & Infiltration Number (I) & $\begin{array}{c}\qquad \mathrm{In}=\mathrm{Dd} \times \mathrm{Fs}_{\mathrm{s}} \\
\text { Where, Dd }=\text { Drainage Density }\left(\mathrm{Km}^{\mathrm{K}} / \mathrm{Km}^{2}\right) \text { and } \mathrm{Fs}=\text { Stream Frequency }\end{array}$ & Zavoiance (1985) \\
\hline 16 & Form Factor Ratio $\left(R_{f}\right)$ & $\begin{array}{c}(\mathrm{Kms}) \mathrm{R}_{\mathrm{f}}=\mathrm{A} / \mathrm{Lb}^{2} \\
\text { Where, } \mathrm{A}=\text { Area of the basin and } \mathrm{L}_{\mathrm{b}}=(\text { Maximum) Basin Length }\end{array}$ & Horton (1932) \\
\hline 17 & Elongation Ratio $\left(\mathrm{R}_{\mathrm{e}}\right)$ & $\begin{array}{c}\qquad \mathrm{Re}=\sqrt{\mathrm{A}} / \pi / \mathrm{Lb} \\
\text { Where, } \mathrm{A}=\text { Area of the Basin }\left(\mathrm{Km}^{2}\right) \mathrm{Lb}_{\mathrm{b}}=\text { Maximum Basin Length }(\mathrm{Km})\end{array}$ & Schumm (1956) \\
\hline 18 & Circularity Ratio $\left(R_{c}\right)$ & 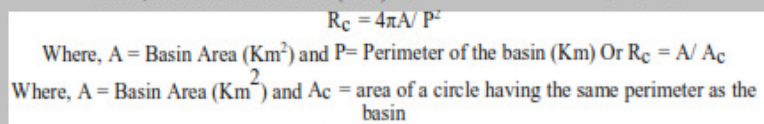 & Miller (1953) \\
\hline 19 & Compactness Coefficient $\left(C_{c}\right)$ & Where $P=$ Basin Perimeter, $A=$ Basin Area & Miller (1953) \\
\hline 20 & $\begin{array}{c}\text { Channel Gradient } \\
\text { Maximum Basin Relief }\end{array}$ & $\begin{array}{c}\text { Relief Morphometric Parameters } \\
C_{\mathrm{p}}=\mathrm{C}_{\mathrm{c}}-\mathrm{E}_{\mathrm{p}} \\
\text { Where, } \mathrm{C}_{\mathrm{c}}=\text { Channel Crest and } \mathrm{E}_{\mathrm{p}}=\text { Elevation of Pour Point } \\
\mathrm{R}_{\mathrm{b}}=\mathrm{E}_{\mathrm{b}}-\mathrm{E}_{\mathrm{bm}} \\
\text { Where, } \mathrm{E}_{\mathrm{b}}=\text { Highest Elevation of Basin and } \mathrm{E}_{\mathrm{bm}}=\text { Elevation of Basin Mouth }\end{array}$ & $\begin{array}{l}\text { Strahler (1964) } \\
\text { Horton (1945); Strahler }\end{array}$ \\
\hline 22 & Relief Ratio & $\begin{array}{l}\qquad R_{t}=R_{b} / L_{b} \\
\text { Where, } R_{b}=\text { Maximum Basin Relief and } L_{b}=\text { Maximum Length of the Basin }\end{array}$ & Schumm (1956) \\
\hline 23 & Basin Slope & $\begin{array}{c}\mathrm{Sw}=\mathrm{H} / \mathrm{Lb} \\
\text { Where } \mathrm{H} \text { and } \mathrm{L}=\text { given above }\end{array}$ & Miller (1953) \\
\hline
\end{tabular}


Morphometric and Landuse Analysis: Implications on Flood Hazards..................AKINWUMIJU, A.S.

Table 3: Physiographic and Landuse Attributes of the Basins

\begin{tabular}{|c|c|c|c|c|c|c|}
\hline S/No. & Parameter & Iwaraja & Ilesa & Olupona & $\begin{array}{l}\text { Osogbo } \\
\text { I }\end{array}$ & $\begin{array}{l}\text { Osogbo } \\
\text { II }\end{array}$ \\
\hline \multicolumn{7}{|c|}{ MORPHOMETRIC } \\
\hline 1 & Basin Order & 4 & 4 & 3 & 4 & 3 \\
\hline 2 & Bifurcation Ratio & $4-4.25$ & $2-6.5$ & $3-4$ & $2-4.5$ & $2.67-3$ \\
\hline 3 & Mean Bifurcation Ratio & 4.08 & 4.32 & 3.50 & 3.61 & 2.84 \\
\hline 4 & Stream Number & 90 & 74 & 17 & 50 & 12 \\
\hline 5 & Stream Length $(\mathrm{km})$ & 124.66 & 109.52 & 21.37 & 37.27 & 9.09 \\
\hline 6 & Stream Frequency & 0.9 & 0.8 & 0.9 & 2.1 & 2.0 \\
\hline 7 & Length of Overland Flow (km) & 0.39 & 0.38 & 0.40 & 0.31 & 0.32 \\
\hline 8 & Basin Length (km) & 15.89 & 19.88 & 7.41 & 9.03 & 4.32 \\
\hline 9 & Drainage Density & 1.2 & 1.3 & 1.2 & 1.6 & 1.5 \\
\hline 10 & Drainage Texture & 1.93 & 1.36 & 0.89 & 2.12 & 1.01 \\
\hline 11 & Basin Area $(\mathrm{km} 2)$ & 97.28 & 82.74 & 17.03 & 22.95 & 5.90 \\
\hline 12 & Basin Perimeter $(\mathrm{km})$ & 46.60 & 54.59 & 19.11 & 23.58 & 11.92 \\
\hline 13 & Main Stream Length $(\mathrm{km})$ & 15.15 & 15.59 & 5.00 & 1.59 & 2.80 \\
\hline 14 & Channel Gradient $(\mathrm{m} / \mathrm{km})$ & 4 & 3.61 & 7.06 & 3.76 & 10.02 \\
\hline 15 & Maximum Basin Relief (m) & 282 & 181 & 84 & 88 & 67 \\
\hline 16 & Relief Ratio & 0.0177 & 0.0091 & 0.0113 & 0.0097 & 0.0155 \\
\hline 17 & Basin Slope & 0.95 & 0.78 & 0.67 & 0.18 & 0.65 \\
\hline 18 & Infiltration Number & 1.16 & 1.17 & 1.24 & 3.53 & 3.13 \\
\hline 19 & Form Factor & 0.38 & 0.21 & 0.31 & 0.28 & 0.32 \\
\hline 20 & Elongation Ratio & 0.20 & 0.15 & 0.18 & 0.17 & 0.18 \\
\hline 21 & Circularity Ratio & 0.56 & 0.35 & 0.59 & 0.51 & 0.52 \\
\hline 22 & Mean Stream Length $(\mathrm{km})$ & 1.39 & 1.48 & 1.26 & 0.70 & 0.76 \\
\hline 23 & Compactness Coefficient & 1.33 & 1.69 & 1.31 & 1.39 & 1.38 \\
\hline \multicolumn{7}{|c|}{ LANDUSE/COVER } \\
\hline 24 & Built Up Area (\%) & 24.54 & 31.44 & 86.57 & 87.30 & 89.40 \\
\hline 25 & Forest and Plantation Agriculture (\%) & 30.39 & 29.21 & - & - & - \\
\hline 26 & Intensive Rainfed Agriculture (\%) & 21.93 & 20.63 & 10.85 & 10.97 & 10.20 \\
\hline 27 & Shifting Cultivation (\%) & 21.80 & 16.95 & 0.52 & 0.46 & 0.06 \\
\hline 28 & Rock Outcrop (\%) & 1.33 & 1.77 & 2.06 & 1.26 & 0.34 \\
\hline 29 & Basin Orientation & SE - NW & SE - NW & NE -SW & NE -SW & NE -SW \\
\hline \multicolumn{7}{|c|}{ LITHOLOGY } \\
\hline & Amphibole Schist $(\%)$ & 20.76 & 76.00 & - & - & - \\
\hline & Banded Gneiss (\%) & 46.57 & 17.07 & 6.46 & 43.64 & 98.64 \\
\hline & Granite Gneiss (\%) & 6.21 & - & - & - & - \\
\hline & Mica Schist (\%) & - & - & 93.54 & 56.36 & 1.36 \\
\hline & Quartz Schist (\%) & 26.46 & 6.93 & - & - & - \\
\hline
\end{tabular}

